\title{
Antibiotic-associated disorders of prothrombin synthesis and their probiotic correction with B. clausii in breastfeed infants
}

\author{
0. G. Ivanko, 0. V. Solianyk
}

Zaporizhzhia State Medical University, Ukraine

Key words:

infant,

Baccilus clausii,

breast feeding,

decarboxy-

prothrombin,

blood coagulation

tests, anti-

bacterial agents.

\section{Zaporozhye}

medical journal

2018; 20 (3), 384-387

Dol:

10.14739/2310-1210

2018.3.130489

E-mail:

iog@ukr.net,

solianik.alex@gmail.com
The aim of the investigation was to study the prothrombin test and PIVKA-II serum levels changes in infants aged 1-6 month after the broad-spectrum antibiotic treatment and determine the possibility of coagulation disorders correction with the help of probiotic Bacillus clausii strains OC, NR, T, SIN spores capable to produce vitamin $\mathrm{K}_{2}$.

Materials and methods. The study involved 57 convalescents after an acute respiratory infection exclusively breastfed infants aged 1 to 6 months one week after the 7-day parenteral treatment with ceftriaxone. Among them 13 children with laboratory signs of blood hypocoagulation (INR > 1.3) had received probiotic Bacillus clausii spores in a daily dose of $2 \times 10^{9} \mathrm{CFU}$ for 10 days. Another 13 children who had not received a probiotic made up a comparison group. Laboratory data was compared with the results of 27 healthy children of the control group. Prothrombin test parameters as a prothrombin (PT), prothrombin time (PTT), international normalized ratio (INR) and protein induced by vitamin $\mathrm{K}$ absence or antagonist II (PIVKA-II) were determined using the hematologic analyzer COAGUCHEC XS and ELISA kit.

Results. It was found that after antibacterial treatment in infants PT was decreased and reached only $50 \%$ of the norm. At the same time, PTT and INR were increased up to 2-folds together with a significant PIVKA-II elevation, which is typical for vitamin K deficiency. The use of probiotic treatment within 10 days has contributed to normalization of prothrombin in 11 out of 13 observed infants versus 3 out of 13 in the comparison group $\left(X^{2}=7.58\right.$ corrected by Yates, $\left.P<0.05\right)$.

Conclusions. Cephalosporin administration for breastfed infants can lead them to latent vitamin $\mathrm{K}$ deficiency development, which is manifested by high levels of PIVKA-II and signs of hypocoagulation development revealed by prothrombin test. The Bacillus clausii probiotic spores prescription to infants after antibiotic therapy course for 10 days normalizes the plasma prothrombin concentration while in children of the comparison group it remains lower than normal.
Киючові слова: грудні діти,

B. clausii,

природне

PIVKA-II,

протромбіновий

тест, антибіотики

Запорізький

медичний

журнал. - 2018. -

T. 20, № 3(108), -

C. 384-387
вигоАовування,

\section{Антибіотикоасоційовані порушення синтезу протромбіну та їх пробіотична корекція за допомогою B. clausiі в дітей на природному вигодовуванні}

\section{О. Г. Іванько, О. В. Соляник}

Мета роботи - вивчити зміни показників протромбінового тесту та вміст у сироватці крові PIVKA-II у грудних дітей перших 6 місяців життя після лікування антибіотиком широкого спектра дії та визначити можливість корекції порушень за допомогою спор пробіотичних штамів OC, NR, T, SIN Bacillus clausii, що здатні виробляти вітамін $\mathrm{K}_{2}$.

Матеріали та методи. У дослідженні взяли участь діти віком від 1 до 6 місяців життя, які отримують тільки грудне вигодовування з народження. Через 7 днів після завершення 7-денного курсу лікування цефтриаксоном обстежили 57 дітей-реконвалесцентів після гострого респіраторного захворювання. 3 них 13 дітей із лабораторними ознаками гіпокоагуляції (МНО $>$ 1,3) протягом 10 днів отримували пробіотичні штами Bacillus clausii в добовій дозі 2 × 109 КУО. 13 дітей, які пробіотик не отримували, ввійшли у групу порівняння. Лабораторні показники порівнювали з результатами 27 здорових дітей контрольної групи. Показники протромбінового комплексу: протромбін за Квіком (ПТ), протромбіновий час (ПТЧ) і міжнародне нормоване відношення (MHB) - визначали за допомогою гематологічного аналізатора COAGUCHEC XS, PIVKA-II - методом IФА.

Результати. Встановлено, що після антибактеріального лікування ПТ становив 50 \% від норми, ПТЧ і МНВ збільшувалися вдвічі при чималому підвищенні концентрації PIVKA-II, що характерне для десріциту вітаміну К. Призначення пробіотика сприяло нормалізації вмісту вітамін-К-залежного протеїну крові протромбіну в 11 із 13 немовлят, а у групі порівняння таких дітей було 3 із 13 ( $x^{2}=7,58$ за Йейтсом, $\left.p<0,05\right)$.

Висновки. Застосування цефралоспорину в дітей перших 6 місяців життя, які отримують грудне вигодовування, може призводити до розвитку прихованого вітамін-К-дефіциту, що проявляється підвищенням сироваткових концентрацій недостатньо карбоксильованого протромбіну (PIVKA-II), зниженням вмісту ПТ, подовженням ПТЧ і збільшенням МНВ. Застосування пробіотичного препарату на основі спор Bacillus clausii в добовій дозі 2 × $10^{\circ}$ КУО протягом 10 днів у дітей, які отримували лікування цефртриаксоном, нормалізує вміст ПТ у плазмі, а в дітей групи порівняння він залишається зниженим.

Ключевые слова: грудные Аети, B. clausii, естественное вскармливание, PIVKA-II, протромбиновый тест, антибиотики.
Антибиотикоассоциированные нарушения синтеза протромбина и их пробиотическая коррекция с помощью B. clausii у грудных детей

\section{О. Г. Иванько, А. В. Соляник}

Цель работы - изучить изменения показателей протромбинового теста и содержание в сыворотке крови PIVKA-II у грудных детей первых 6 месяцев жизни после лечения антибиотиком широкого спектра действия и определить возможность коррекции нарушений с помощью спор пробиотических штаммов OC, NR, T, SIN Bacillus clausii, способных вырабатывать витамин $\mathrm{K}_{2}$.

Материалы и методы. В исследовании участвовали дети в возрасте от 1 до 6 месяцев жизни, находящиеся на исключительно грудном вскармливании с момента рождения. Через 7 дней после окончания 7-дневного курса лечения цефртриаксоном 
обследовали 57 детей-реконвалесцентов после острого респираторного заболевания. Из них 13 детей с лабораторными признаками гипокоагуляции (MHO > 1,3) в течение 10 дней получали пробиотические споры Bacillus clausii в суточной дозе $2 \times 10^{9} \mathrm{KOE}$. Еще 13 детей, которые пробиотик не получали, составили группу сравнения. Лабораторные показатели сравнивали с результатами 27 здоровых детей контрольной группы. Показатели протромбинового комплекса: протромбин по Квику (ПТ), протромбиновое время (ПТВ) и международное нормированное отклонение (МНО) - определяли с помощью гематологического анализатора COAGUCHEC XS, a PIVKA-II - методом ИФА.

Результаты. Установлено, что после антибактериального лечения ПТ составил 50 \% от нормы, ПТВ и МНО увеличились в 2 раза при значительном повышении концентрации PIVKA-II, что характерно для дефицита витамина К. Назначение пробиотика способствовало нормализации содержания витамин-К-зависимого протеина крови протромбина у 11 из 13 младенцев, в то время как в группе сравнения таких детей было 3 из 13 ( $X^{2}=7,58$ по Йетсу, $\left.p<0,05\right)$.

Выводы. Применение цефалоспорина у детей первых 6 месяцев жизни, получающих грудное вскармливание, может вести к развитию скрытого витамин-К-дефицита, который проявляется повышением сывороточных концентраций недостаточно карбоксилированного протромбина (PIVKA-II), снижением содержания ПТ, удлинением ПтВ и увеличением МНО. Применение пробиотического препарата на основе спор Bacillus clausii в суточной дозе $2 \times 10^{9}$ КОЕ в течение 10 дней у детей, получивших лечение цефтриаксоном, нормализует содержания ПТ в плазме, а у детей группы сравнения он остается сниженным.

\section{Introduction}

Antibiotics are able to cause a variety of side effects. There are well-known cases of diarrhea (ICD-10 A7) associated with a change in the ratio of microbial organisms inhabiting the intestine with an uncontrolled increase in a number of microbes capable to exhibit aggressive properties. It is quite obvious that some intestinal symbiotics (Bacteroides, Enterobactericae and several other), that participate in $\mathrm{B}$ group, PP, etc., vitamins synthesis in colon can also be suffered from antibiotic depressive influences. The role of colonic microbiota in providing children and adults with vitamins $\mathrm{K}_{2}$ (menaquinones) is essential. The fact is that the cycle of vitamin $\mathrm{K}$ in newborns and infants of the first 6 months of life is characterized by instability which in its extreme clinical manifestation may be manifested by early or late neonatal hemorrhagic disease associated with vitamin $\mathrm{K}$ deficiency (ICD-10 P-53). In common situations the latent vitamin $\mathrm{K}$ deficiency is related to some ontogenetic "expediency" that counteracts the risk of pregnancy-associated disseminated intravascular coagulation, low fetal vitamin $\mathrm{K}$ supply, the absence of significant depot due to insufficient transport through placenta and extremely small amounts of the vitamin in breast milk unable to provide the child physiological needs. Vitamin $\mathrm{K}$ deficient complications treatment after delivery overcomes by vitamin $\mathrm{K}_{1}$ (phylloquinone) intramuscular bolus administration in an amount of $1 \mathrm{mg}$ which corresponds to 40 daily doses for infant [1]. Children who are fed with modern milk formulas get enough vitamins including vitamin $\mathrm{K}$ because of feeding fortification in accordance with age-related needs of children. However infants, who are exclusively breastfed after 8 days of life, fall into the risk of hypovitaminosis K again after fast elimination of the phylloquinone given to a newborn immediately after the birth as a bolus. At the same time, cases of the late hemorrhagic disease in healthy infants are relatively rare. At the age of 1 month the laboratory signs of vitamin $\mathrm{K}$ deficiency spontaneously disappear what can be explained by the colonic microbiota activity and its vitamin K-producing component [2]. During the following months despite the vitamin $\mathrm{K}$ deficiency in food persistence in the absence of additional vitamin supplementation the metabolic cycle of vitamin $\mathrm{K}$ is maintained only by intestinal microorganisms.

Many diseases can disrupt labile balance of vitamin $\mathrm{K}$ supplementation in infants. Liver and intestinal diseases including colonic microbiota disturbances can cause significant impact on vitamin $\mathrm{K}$ synthesis, absorption and biotransformation. An unique feature of vitamin $\mathrm{K}$ cycle is a very rapid development of hypovitaminosis which commonly clinically manifests as bleeding. For example, the use of vitamin $\mathrm{K}$ antagonist warfarin can lead to blood hypocoagulation as early as the $2-3$ day after administration [3].

The role of vitamin $\mathrm{K}$ in humans is being intensively studied. The concept of "vitamin K" combines a number of biochemical derivatives (vitamers) of 2-methyl-1, 4-naphthoquinone, which have approximately the same function. All of them are co-factors for the $\mathrm{y}$-glutamyl carboxylase enzyme which is essential for a number of plasma proteins, bone tissue, blood vessels and myocardium carboxylation by the way of replacement the carboxyl radical (Gla residue) instead of the glutamine radical (Glu residue). The classic human vitamin $\mathrm{K}$-dependent protein is a prothrombin. This is one of the most important serum clotting factors (factor II) which in its posttranscriptional modification needs a carboxylation with the participation of vitamin $\mathrm{K}$. The approved biochemical sign used for vitamin $\mathrm{K}$ deficiency evaluation is a high plasma concentration of the Glu residues of prothrombin or the PIVKA-II (protein induced by vitamin $\mathrm{K}$ absence or undercarboxylated prothrombin) [4]. In lack of the functionally mature Gla residue of prothrombin the signs of vitamin K-deficient hypocoagulation develop: the level of prothrombin decreases and so called prothrombin time and bleeding time get slower. Although there are some information that the commonly used prothrombin test may be dependant on a treatment with antibiotics [5], the mechanisms and clinical importance of this phenomenon have not been enough studied.

\section{The aim}

The aim of the investigation was to study the prothrombin test and PIVKA-II serum levels changes in infants aged 1-6 month after the broad-spectrum antibiotic treatment and determine the possibility of coagulation disorders correction with the help of probiotic Bacillus clausii strains OC, NR, $T$, SIN spores capable to produce vitamin $\mathrm{K}_{2}$.

\section{Materials and methods}

The study involved 84 children aged 1 to 6 month. There were $50(59.5 \%)$ boys and $34(40.5 \%)$ girls. All children were born at the 38-40-th week of gestation after vaginal
Запорожский медицинский журнал. - 2018. T. 20, № 3(108). C. 384-387 
Table 1. Prothrombin test and PIVKA-II values in infants received antibiotic treatment in comparison with healthy children $(\mathrm{M} \pm \mathrm{m})$

\begin{tabular}{l|l|l|l|l|l} 
Children groups & $\mathrm{n}$ & INR (un.) & PTT (sec) & PT (\%) & PIVKA-II (Au/ml) \\
\hline Treated with antibiotic & 31 & $2.60 \pm 0.80$ & $53.8 \pm 10.1$ & $38.1 \pm 5.8$ & $129.6 \pm 33.1$ \\
Healthy (control) & 27 & $1.14 \pm 0.13$ & $24.9 \pm 5.1$ & $85.8 \pm 9.5$ & $26.9 \pm 4.7$ \\
$\mathrm{P}$ & & $<0.050$ & $<0.001$ & $<0.001$ & $<0.001$ \\
\hline
\end{tabular}

INR: the international normalized ratio; PTT: prothrombin time; PT: prothrombin;

PIVKA-II: protein induced by vitamin K absence; P: the probability of statistical error.

Table 2. Prothrombin complex values in dynamics of a 10-day length observation in infants who have received Bacillus clausii probiotic spores and in the control group

\begin{tabular}{|c|c|c|c|c|c|c|c|}
\hline \multirow[t]{2}{*}{ Children groups } & \multirow[t]{2}{*}{$n$} & \multicolumn{3}{|l|}{ At the start } & \multicolumn{3}{|c|}{ At the finish } \\
\hline & & $\begin{array}{l}\text { INR (un.) } \\
M \pm m\end{array}$ & \begin{tabular}{|l|}
$\mathrm{PTT}$ (sec) \\
$\mathrm{M} \pm \mathrm{m}$
\end{tabular} & \begin{tabular}{|l|} 
PT (\%) \\
$M \pm m$
\end{tabular} & $\begin{array}{l}\text { INR (un.) } \\
M \pm m\end{array}$ & $\begin{array}{l}P T T \text { (sec) } \\
M \pm m\end{array}$ & $\begin{array}{l}P T(\%) \\
M \pm m\end{array}$ \\
\hline $\begin{array}{l}\text { Treatment with } \\
\text { Bacillus clausii }\end{array}$ & 13 & $2.69 \pm 0.65$ & $32.4 \pm 7.7$ & $33.3 \pm 4.6$ & $1.05 \pm 0.03$ & $12.5 \pm 0.4$ & $93.7 \pm 4.0$ \\
\hline Control & 13 & $3.08 \pm 0.71$ & $36.9 \pm 8.5$ & $33.9 \pm 6.1$ & $1.19 \pm 0.04$ & $14.2 \pm 0.4$ & $75.0 \pm 4.1$ \\
\hline P & & $>0.500$ & $>0.500$ & $>0.900$ & $<0.010$ & $<0.010$ & $<0.005$ \\
\hline
\end{tabular}

INR: the international normalized ratio; PTT: prothrombin time; PT: prothrombin;

P: the probability of statistical error.

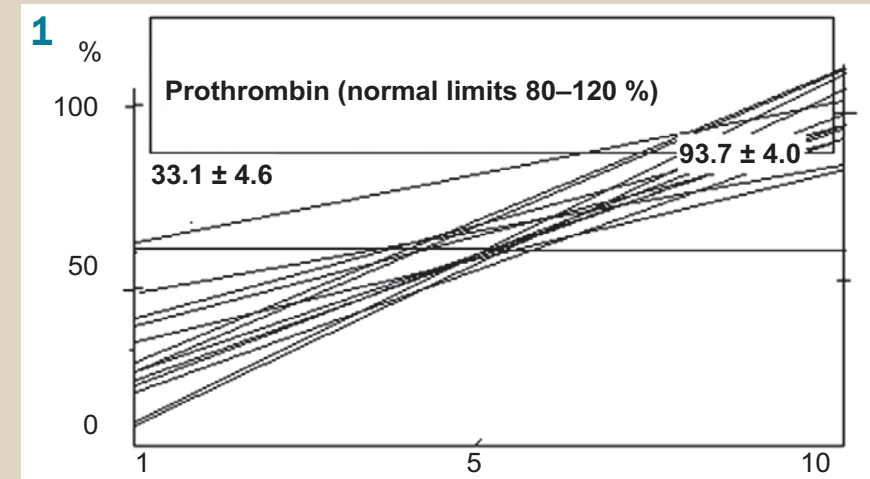

Days of observations

Bacillus clausii 2 x 10 E9 CFU/day

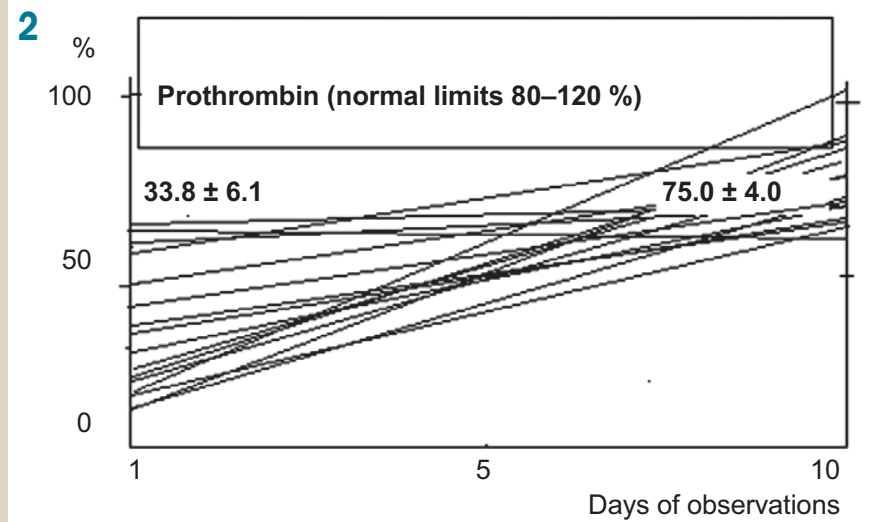

Fig. 1. Plasma prothrombin (\%) concentrations in infants in dynamics of 10-day length probiotic therapy (1) and in control (2).

delivery without birth trauma and scored $7-10$ points according to Apgar scale. Infants were exclusively breastfed from the moment of the birth. Among them 40 (48\%) children received an intramuscular injection of $1 \mathrm{mg}$ vitamin $\mathrm{K}_{1}$ for hemorrhagic disease of newborns early prevention in accordance with the current recommendations. Other 43
(53\%) children did not receive vitamin $\mathrm{K}_{1}$ due to various reasons among which most often there were the parents' refusals because of some fears if the child could be traumatized with an "extra" injection. The main part of the study was based on observations of 57 convalescents after an acute respiratory infection (non-severe community-acquired pneumonia) or acute otitis media one week after the 7-day length parenteral treatment with ceftriaxone at a daily dose of $50-80 \mathrm{mg} / \mathrm{kg}$. Clinical observations were carried out in the Department of Neonatal Pathology and Early Childhood Diseases in the Pediatric Hospital № 5, Zaporizhzhia.

The hematology analyzer COAGUCHEC XS (Germany) examined the capillary blood for the traditional parameters of the prothrombin complex. There were the plasma prothrombin (PT) as a percentage of the "ideal" level in the reference plasma (normal values within 80-120\%), prothrombin time (PTT) (usual limits 11-18 sec.) and international normalized ratio (INR) (0.9-1.3). The INR is a derivative parameter of the PTT in form of patient prothrombin time ratio to normal plasma prothrombin time in power of mathematical corrective units by which a laboratory standardization of the prothrombin time can be made.

Concentrations of PIVKA-II were studied in the venous blood serum. The enzyme-linked immunoassay for PIVKA-II determination was carried out with the diagnostic ANTIBODY RESEARCHPIVKA-II ELISAKit (USA) and the SirioS SEACa I RADIM analyzer (China) in the Central Research Laboratory of Zaporizhzhia State Medical University.

The obtained clinical and laboratory data allowed to compare the cohort of 31 children grouping in accordance to antibacterial treatment impact and the control cohort of 27 healthy children. The hypothesis whether the probiotic therapy with Bacillus clausii be capable to restore low plasma prothrombin in breastfed infants after antibiotic therapy was figured out in controlled study of two reference groups. All of them were children grouped according to elevated INR $>1.3$ criterion. However, they were free from any evident signs of bleeding. In addition, children did not demonstrate diarrhea, jaundice, hypoproteinemia, AST/ALT elevation. By fixed randomization 13 patients were assigned for 10-day length probiotic therapy in a daily dose of $2 \times 10^{9}$ colonies formed units (CFU) OC, NR, T, SIN strains spores of Bacillus clausii which vegetative microorganisms are capable to produce menaquinones [6,7]. Another 13 infants corresponding to the age, sex, feeding type and laboratory values were not given probiotics. They made up a comparison group. Simultaneously all children received a standard therapy with mucolytic and vitamin D3.

Statistical processing was carried out using certified programs Statistica 6.0 (StatSoft, USA) (license No. 31415426535897).

\section{Results and discussion}

As it is shown in Table 1, the parameters of vitamin K-dependent procoagulant plasma proteins in breastfed infants depend significantly on the fact of cephalosporin administration.

As it follows from the data in Table 1, healthy infants aged 1-6 month achieved almost normal levels 
of prothrombin test comparable to those in adults with the exception of PTT slight prolongation. Although breast milk feeding formally unable to provide sufficient intake of vitamin $\mathrm{K}$ with food, healthy children shown an acceptable levels of serum Gla prothrombin (PIVKA-II) which indicates the absence of significant vitamin K-deficiency. It means that in healthy children the intestinal microbiota can provide them with vitamin $\mathrm{K}$. In turn, the microbiota is susceptible to the damage associated with antibacterial therapy exposure. In response to the ceftriaxone administration infants had laboratory signs of hypocoagulation sufficient enough for late hemorrhagic disease of newborns development. Thus the level of PT after the antibacterial course was only $50 \%$ of the norm, PTT and INR were increased more than 2 times with substantially increased PIVKA-II serum concentrations typical for vitamin $\mathrm{K}$ deficiency.

These changes should be explained by an antibiotic-associated impact on menaquinone synthesizing colonic microflora. In accordance with the background of the study, an attempt of colon microbiota therapeutic correction by the administration of Bacillus clausii probiotic strain, which vegetative forms are capable to produce menaquinones in the human large intestine, was studied. The results are shown in Table 2.

As it follows from Table 2, the prothrombin complex values in both of the clinical and control groups are characterized by a tendency toward their normalization after the antibacterial therapy discontinuing. It is explained by the intestinal microbiome ability to quantitive and qualitive self-repairing and accordingly to improvement in the availability to provide children with menaquinones. Simultaneous administration of the Bacillus clausii probiotic has promoted more complete prothrombin normalization. As it is shown in the Fig. 1, the full values of this vitamin K-dependent protein restoration in 10 days of probiotic therapy was noted in 11 out of 13 infants, while among the children of the control group there were only 3 such infants out of $13\left(X^{2}=7.58\right.$, corrected by Yates, $\mathrm{P}<0.05$ ).

\section{Conclusions}

1. Parenteral cephalosporin administration in breastfed infants aged 1-6 month can lead to a latent vitamin K-deficient state development, which is manifested by a significant PIVKA-II serum concentrations increasing, plasma prothrombin decreasing and prolongation of prothrombin time with elevation of international normalized ratio.

2. The use in infants the probiotic spores of Bacillus clausii in a daily dose of $2 \times 10^{9}$ CFU for 10 days after antibiotic treatment restores the plasma prothrombin levels.

The prospects of further research. It would be expedient to recommend the probiotic spores of Bacillus clausii administration to infants especially who is breastfed immediately during the antibiotic therapy. A probiotic preparation, which can positively influence on the intestinal microbiota state increasing the vitamin $\mathrm{K}_{2}$ supplementation, should be investigated in comparison with vitamin $\mathrm{K}_{1}$ enteral administration in their ability to improve the plasma coagulation capacity in infants receiving exclusively breast milk.
Фінансування: АосліАження виконане в рамках НАР Запорізького Аержавного медичного університету «Умови, що впливають на забезпеченість Аітей перших місяців життя вітаміном К та шляхи їх корекції» № Аержреєстрації 0115U003872 (2015-2019).

Conflicts of Interest: authors have no conflict of interest to declare. Конфлікт інтересів: віАсутній.

Information about authors:

Ivanko 0. G., MD, PhD, DSc, Professor, Head of the Department of Propaedeutics of Children's Diseases, Zaporizhzhia State Medical University, Ukraine.

Solianyk O. V., MD, Assistant, Department of Propaedeutics of Children's Diseases, Zaporizhzhia State Medical University, Ukraine.

Відомості про авторів:

Іванько О. Г., А-р меА. наук, професор, зав. каф. пропедевтики Аитячих хвороб, Запорізький Аержавний меАичний університет, україна.

Соляник О. В., асистент каф. пропедевтики дитячих хвороб,

Запорізький Аержавний медичний університет, Україна.

\section{Сведения об авторах:}

Иванько О. Г., А-р меА. наук, профессор, зав. каф. пропедевтики Аетских болезней, Запорожский государственный медицинский университет, Украина.

Соляник А. В., ассистент каф. пропедевтики детских болезней, Запорожский государственный медицинский университет, Украина.

Надійшла Ао редакції / Received: 18.12.2017

Після Аоопрацювання / Revised: 28.12.2017

Прийнято Ао Аруку / Accepted: 15.01.2018

\section{References}

[1] Nakaz Ministerstva okhorony zdorovia Ukrainy «Pro zatverdzhennia Protokolu medychnoho dohliadu za zdorovoiu novonarodzhenoiu dytynoiu» vid 04.04.2005 riku №152 [Order of the Ministry of Health of Ukraine «Protocol for the care of a healthy newborn» from April, 4, 2005, №152]. [in Ukrainian].

[2] Ivan'ko O. G., \& Solyanik, A. V. (2016). PIVKA-II kak pokazatel' deficyta vitamina $\mathrm{K}$ u detej pervykh mesyacev zhizni, poluchayushhikh isklyuchitel'no grudnoe vskarmlivanie. Ukrainskoe issledovanie [PIVKA-II as an indicator of vitamin $\mathrm{K}$ deficiency in children of the first months of life who are exclusively breastfed. The Ukrainian study]. Zdorov'e rebenka, 7(75), 95-100 [in Russian].

[3] Novikova, N. A., \& Volovchenko, A. N. (2016). Varfarin: mesto v sovremennoj antikoagulyantnoj terapii [Warfarin: place in the anticoagulant therapy today]. Aterotromboz, 1, 50-58 [in Russian].

[4] Chawla, D., Deorari, A. K., Saxena, R., Paul, V. K., Agarwal, R., Biswas, A., \& Meena, A. (2007) Vitamin K1 versus vitamin K3 for prevention of subclinical vitamin deficiency: a randomized controlled trial. Indian Pediatrics, 44(11), 817-22.

[5] Ero, M. P., Harvey, N. R. Harbert, J. L., Janc, J. W., Chin, K. H., \& Barriere, S. L. (2014) Impact of telavancin on prothrombin time and activated partial thromboplastin time as determined using point-of-care coagulometers. J Thromb Thrombolysis, 38(2), 235-40. doi: 10.1007/ s11239-013-1004-y.

[6] Hosoi, T. \& Kiuchi, K. (2003) A food made by fermenting cooked soybeans with Bacillus subtilis. Handbook of fermented Functional Foods. Boca Raton, Fla: CRC Press.

[7] Yong, A. B. (patentee) (2011) Patent WO20111589989 (A1) Strain of bacillus amyloliquefaciens having a high vitamin $\mathrm{k} 2$ producing ability. 